\title{
FUNCTIONAL ATTRIBUTES AS ECOLOGICAL PREDICTORS DURING SECONDARY SUCCESSION IN A SEASONAL DECIDUOUS FOREST IN SOUTHERN BRAZIL
}

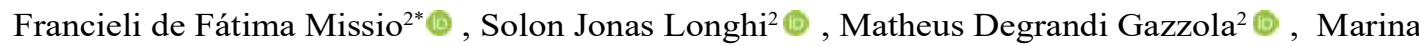 \\ Scheuer $^{2} \odot$, Rodrigo Pinto da Silva ${ }^{2} \odot$ and José Augusto Spiazzi Favarin ${ }^{3}$ (C)
}

\footnotetext{
${ }^{1}$ Received on 18.06.2019 accepted for publication on 20.01.2020.

${ }^{2}$ Universidade Federal de Santa Maria, Centro de Ciências Rurais, Santa Maria, RS - Brasil. E-mail: <franmissio@yahoo.com.br $>,<$ longhi. solon@gmail.com>,<d.gazzola.gmail.com>,<marina.scheuer@gmail.com> and < srodrigopinto.96@gmail.com>.

${ }^{3}$ Universidade Federal do Paraná, Programa de Pós-Graduação em Engenharia Florestal, Curitiba, PR - Brasil. E-mail: <jazflorestal@ yahoo.com.br>.

*Corresponding author.
}

\begin{abstract}
Through the variation of the functional attributes, it is possible to verify the functioning of an ecosystem, both by the species organization as by their responses to the environmental variations. In this sense, the objective of this study was to analyze the ecological strategies of the main tree species by analyzing their functional attributes. PCoA was used to verify which species are acquisitive and conservative; clustering was used to verify the functional attributes by groups; the Pearson's correlation between the functional attributes and a CWM-RDA analysis was used to verify the environmental variables. Most species were classified as light-demanding climax and having zoochoric dispersion. The species presented phenotypic plasticity as an important ecological strategy in the composition of their functional attributes, especially when related to leaf area and specific leaf area. Most of the species belonged to the acquisitive group. The acquisitive and conservative groups indicate the resilience potential of the tree community and the change processes in ecological succession. There was a strong negative correlation between the leaf attributes, and a positive one with diameter and height, both correlations related to plant growth and development. Of the environmental variables only $\mathrm{pH}, \mathrm{K}$, and average elevation, were related to the attributes, indicating that environmental conditions are important for the establishment of the sampled species. Also, it was found that the species composition is linked to several conditions of ecological strategies associated with changes in the environment. Keywords: PCoA; CWM-RDA; Pearson's correlation.
\end{abstract}

\section{ATRIBUTOS FUNCIONAIS COMO PREDITORES ECOLÓGICOS DURANTE A SUCESSÃO SECUNDÁRIA EM FLORESTA ESTACIONAL DECIDUAL, SUL DO BRASIL}

\begin{abstract}
RESUMO - Através da variação dos atributos funcionais é possivel verificar o funcionamento do ecossistema, tanto pela organização das espécies como pelas respostas das mesmas em relação as variações do ambiente. Nesse sentido, o objetivo foi analisar as características ecológicas das principais espécies arbóreas, pela análise dos atributos funcionais. Utilizou-se uma PCoA para verificar quais espécies são aquisitivas e conservativas; cluster na verificação dos atributos funcionais por grupos; correlação de Pearson entre os atributos funcionais e uma análise CWM-RDA na verificação das variáveis ambientais. A maioria das espécies foram classificadas como clímax exigente de luz e com dispersão zoocórica. As espécies apresentaram a plasticidade fenotípica como importante estratégia ecológica na composição dos seus atributos funcionais, principalmente quando relacionadas a área foliar e área foliar especifica. A maioria das espécies pertenceram ao grupo das aquisitivas. O grupo das aquisitivas e conservativas indicam o potencial de resiliência da comunidade arbórea e os processos de mudança na sucessão ecológica. Foi verificada forte correlação negativa entre os atributos foliares e positiva com diâmetro e altura, ambas as correlações relacionadas ao crescimento-desenvolvimento da planta. Das variáveis ambientais, apenas $\mathrm{pH}, \mathrm{K}$ e cota média tiveram relação com os atributos, indicando
\end{abstract}

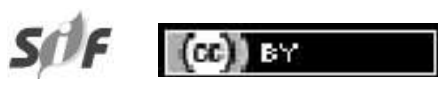

Revista Árvore 2020;44:e4423 http://dx.doi.org/10.1590/1806-908820200000023 
ser importantes condições ambientais para o estabelecimento das espécies amostradas. Além disso, verificouse que a composição de espécies está atrelada a várias condicionantes de estratégias ecológicas associadas com as mudanças no meio ambiente.

Palavras-Chave: PCoA; CWM-RDA; Correlação de Pearson.

\section{INTRODUCTION}

The transformation of vegetation from continuous areas into isolated remnants or modified vegetation portrays the effect of anthropic action which decreases species richness, carbon stock, as well as ecosystem activities which altogether interfere in the structuring and functioning of the ecosystem (Laurance et al., 2006).

In turn, ecosystem functioning is related to the abiotic and biotic environments present within it (Mayfield, 2006). Thus, the set of plants with their combined functional attributes determine these relationships of ecological aptitude, both by the interactions between species and by their ways of responding to environmental variations (Sosinski-Júnior and Pillar, 2004).

In areas which have generally been abandoned after agricultural activity, for example with poorly managed soils, natural regeneration improves soil conditions by depositing organic matter and nitrogen availability. The improvement in soil quality, water retention and fertility favor colonizing less tolerant species to below ground stresses and those which are more tolerant to canopy cover rates (Chazdon, 2016).

Thus, functional attributes are considered as all the morphological and physiological characteristics which influence the establishment, development and survival of a plant (Violle et al., 2007) and the combination of these attributes represents the ecological strategies of the plants regarding their acquisition and use of resources available in the environment (Pérez-Harguindeguy et al., 2013). Likewise, it is important to note that these characteristics distinguish species at different succession stages which are determinants of the demographic rate and direct changes and tree composition during forest regeneration (Chazdon, 2016). The species are established according to the availability of resources and investment capacity, called conservative and acquisitive (Diaz et al., 2004; Reich, 2014), which represent this partition context of ecological niches, vertical forest structure and population distribution by environmental gradient (Sousa et al., 2017). In other words, these two considered categories refer to their acquisition and resource usage strategies, for example rapid growth (acquisitive) and slow growth (conservative).

These ecological strategies can lead to inferences regarding the resilience potential of a fragmented area. Combining the measurements of functional attributes in facing the similarity of their ecological functions can clarify the role of the tree community (Freitas and Mantovani, 2017) through the set of plants with functional redundancy, meaning strategies of similar ecological conditions, in which the condition for them to be allocated in areas under anthropic disturbance is verified (Pillar et al., 2013).

Therefore, considering the importance of understanding and interpreting the multiple ecological relationships which influence secondary succession, the study aims to: measure the functional traits of the main tree species present in the floristic composition in order to infer their distribution in functional groups (acquisitive or conservative) and their ecological interactions; to analyze which environmental variations influenced the species in relation to their functional attributes in a stretch of Seasonal Deciduous Forest on the edge of the Southern Plateau of Rio Grande do Sul, Brazil.

\section{MATERIAL AND METHODS}

\subsubsection{Study area location and characterization}

The study was carried out in a stretch of Seasonal Deciduous Forest (IBGE, 2012), at the coordinates $29^{\circ} 35^{\prime} 19.19^{\prime \prime S}$ and $53^{\circ} 21^{\prime} 47.63^{\prime \prime} \mathrm{W}$, municipality of Dona Francisca, in the region of Quarta Colônia, RS, Brazil. The region's climate is classified as humid Cfa - Subtropical, with maximum temperatures of $18^{\circ} \mathrm{C}$ in winter and above $22^{\circ} \mathrm{C}$ in summer, with rains well distributed throughout the year (Alvares et al., 2013).

The forest stretch is inserted on a slope and has approximately $7 \mathrm{ha}$, with an average altitude of approximately $153 \mathrm{~m}$. In addition to presenting springs

Revista Árvore 2020;44:e4423 
and water courses, it is also possible to verify a wavy to strong wavy relief on a discontinuous level, as well as soils in the region being classified as Argisol and Cambisol associated with Neossol (Pedron and Dalmolin, 2011).

The area is inserted in an anthropic matrix upon which agriculture and livestock practices predominate. The vegetation is considered secondary, since there was a clear cut in the area for tobacco growing. The vegetation was recovered through natural regeneration after abandonment of the area approximately 50 years ago. Thus, 50 plots in 10 parallel strips in the base direction to the top of the slope measuring $10 \times 20 \mathrm{~m}\left(200 \mathrm{~m}^{2}\right)$ were installed for the floristic survey and phytosociological study. The plots were allocated following the systematic pattern, being $10 \mathrm{~m}$ apart and $40 \mathrm{~m}$ between the strips, sampling 1 ha of forest (Figure 1).

\subsubsection{Determining the functional attributes}

A total of 19 native tree species, which represented $84.4 \%$ of the vegetation cover, were selected from the analysis of the phytosociological estimators to study their functional attributes (Missio, 2019). This species selection criterion was used according to the methodology proposed by Cornelissen et al. (2003) and Perez-Harguindeguy et al. (2013), who state that the abundance of species composing $80 \%$ of the floristic composition is sufficient to represent it as a whole.

Next, 10 individuals per species were randomly selected from 50 plots to measure their functional

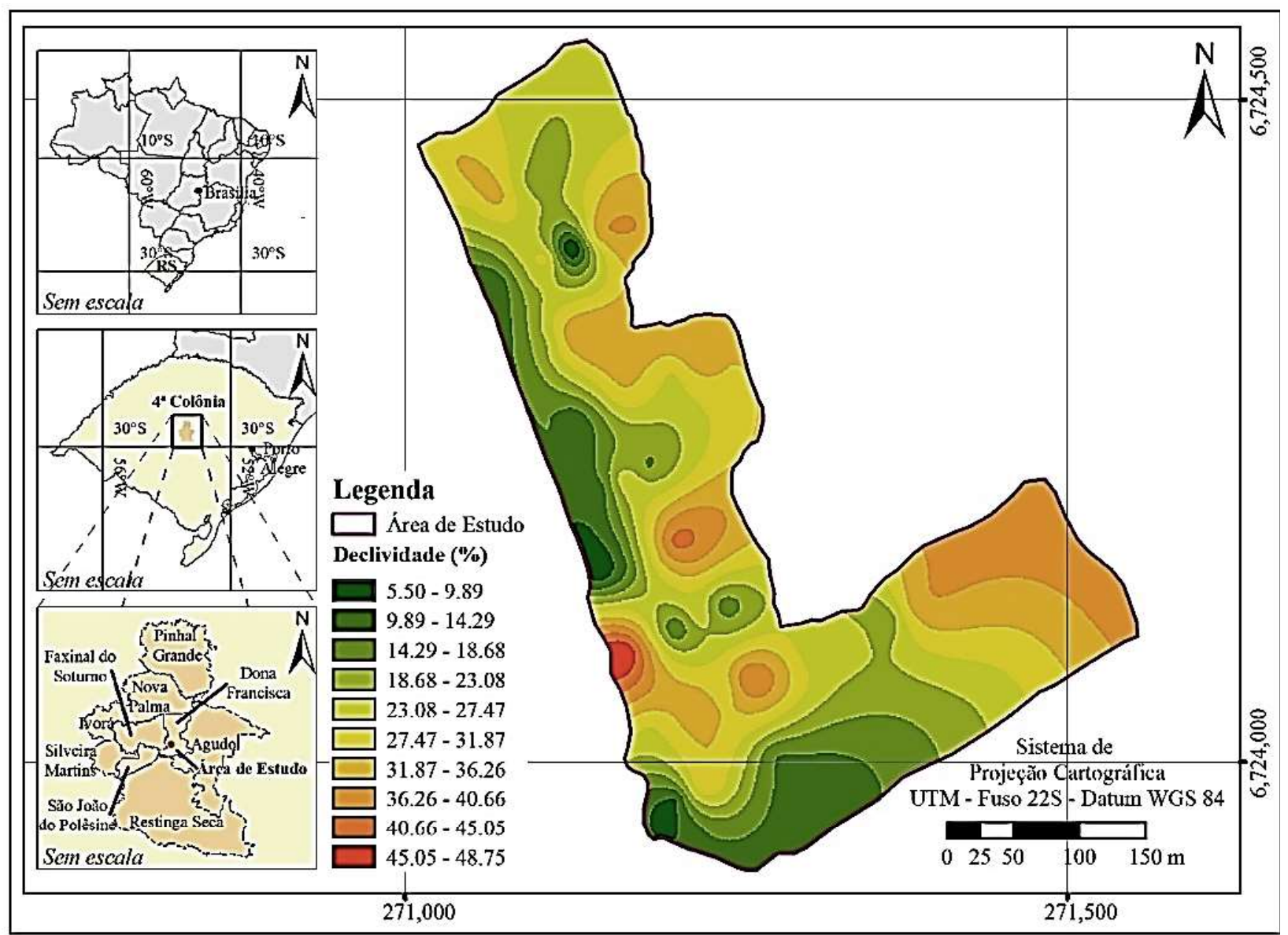

Figure 1 - Geographic location and representation of the study area with the respective slope. Figure 1, left is the Brazilian map, followed by the region of the Fourth Colony with the provision of the municipalities and study area.

Figura 1 - Localização geográfica e representação da área de estudo com a respectiva declividade. Sendo, figura 1, a esquerda com o mapa brasileiro. Seguida da região da Quarta Colônia com a disposição dos municípios e área do estudo. 
attributes (leaf area, specific leaf area, maximum height and maximum diameter). First, 20 leaves were collected from each individual from the middle to upper third of the crown, with luminous incidence, and preferably healthy ones in order to determine the leaf area and specific leaf area (Pérez-Harguindeguy et al., 2013). Later, the leaves were photographed in the laboratory and the leaf area was determined using the ImageJ program (Rasband, 2007). The leaves were subsequently put into an oven until they reached constant weight. The specific leaf area was then determined by the ratio between the leaf area $\left(\mathrm{cm}^{2}\right)$ and dry weight $(\mathrm{g})$. Next, those with the 10 highest values were selected and the means for height and DBH was performed (Pérez-Harguindeguy et al., 2013). A specialized literature review was conducted for the categorical functional attributes (dispersion syndrome, regeneration guilds and leaf renewal regime), with species separated into zoochoric, anemochoric and autochoric; pioneers, light-demanding climax and shade-tolerant climax; deciduous or evergreen (Van der Pijl, 1982; Oliveira- Filho et al., 1994; Lorenzi, 1998; Lorenzi, 2000; Carvalho, 2003).

\subsubsection{Collection of environmental variables}

Soil samples were collected in each of the 50 installed plots and the chemical and physical properties were determined by the Soil Analysis Laboratory of the Soil Department of UFSM. Next, $\mathrm{pH}\left(\mathrm{pH}\right.$ in $\left.\mathrm{H}_{2} \mathrm{O}\right)$, phosphorus $(\mathrm{P})$, potassium $(\mathrm{K})$, soil organic matter (SOM\%), aluminum (Al), calcium $(\mathrm{Ca})$, and magnesium $(\mathrm{Mg})$ were used as the chemical properties, and potential acidity $(\mathrm{H}+\mathrm{Al})$, effective $\mathrm{CEC}(\mathrm{CECef}), \mathrm{CEC}$ at $\mathrm{pH}=$ 7 ( $\mathrm{CECpH} 7)$, base saturation (V\%), and aluminum saturation $(\mathrm{m} \%)$ were calculated. Moreover, sand $\%$, silt $\%$, and clay $\%$ were quantified as physical properties according to Embrapa (2011).

Topographic variables: average elevation (m), maximum elevation $(\mathrm{m})$ and average slope $(\%)$ were obtained in each plot using the Global Positioning System (GPSMAP 76CSx) and a Suunto clinometer according to the methodology adapted from OliveiraFilho et al. (1994).

The stony percentage of each plot was performed visually and classified into four classes according to the methodology adapted from Santos et al. (2013). The canopy coverage was obtained using the concave spherical densiometer model A (Lemmon, 1957) through four readings in the north, south, east and west directions at the center of each plot.

\subsubsection{Data analysis}

A matrix with functional attributes and tree species was used and transformed into a dissimilarity matrix by Gower's distance (Gower, 1971), and a PCoA ordering was also performed to separate tree species in relation to their ecological strategies, considering acquisitive (quick return in investment) or conservative (invest in the long term in acquiring resources). Acquisitive species are those which have a negative relationship with the axis and conservative species have positive values (Silva et al., 2015). Next, a Cluster analysis was performed using the same matrix in order to verify which functional attributes are important in forming functional groups considering the species separated into acquisitive and conservative through the UPGMA connection method. The effectiveness of this analysis was verified by the cophenetic correlation coefficient (Legendre and Legendre, 1998; Borcard et al., 2011).

Continuous functional attributes were subsequently used for the next two analyzes. According to Laureto et al. (2015), in some investigations it is preferable to select the attributes which best match the structure of the tree community and which represent the close relationship between species and the environment in order to understand the ecosystem processes of interest, therefore selecting the key quantitative attributes which are generally more effective in identifying interspecific variability. Thus, Pearson's correlation (Legendre and Legendre, 1998) was used in order to analyze the dependence between these functional attributes and in the composition of the species in these groups. It varies from -1 to 1 , with the closer to the extremes representing a greater positive or negative linear relationship.

Next, a matrix of the functional attributes of each species was generated by its abundance per plot to verify the response of the functional attributes in relation to the environmental variables sampled in the forest stretch. This was performed using the CWM technique (community weighted mean, constituting the weighted average of the attributes of the community) according to Garnier et al. (2004), and an RDA redundancy analysis was performed to plot the functional attributes and their significant environmental variables $(p<0.1)$. All analyzes were performed using the R statistical software program with the main packages such as vegan, FD and ade4 (R Development Core Team, 2018).

Revista Árvore 2020;44:e4423 


\section{RESULTS}

Considering the categorical and continuous attributes (Table 1), three species were considered as shade-tolerant climax and the rest as light-demanding climax. There was only one species with autochory dispersion syndrome, four anemochoric species and 14 were zoochoric. Regarding the leaf renewal regime, seven were deciduous and 12 perennial. For the continuous attributes, the species with larger leaves were Cabralea canjerana and Cedrela fissilis. The species with smaller leaves was Casearia decandra. Furthermore, Cedrela fissilis, Machaerium paraguariense and Casearia decandra stood out from the others regarding the highest value observed for the specific leaf area, demonstrating that they are less long-lived leaf species, less resistant to physical and biological conditions, as well as investing less in the leaf structure when compared to other tree species. Actinostemon concolor had a shorter height and smaller diameter, which was expected because it is a kind of understory, and the opposite of what was observed for Nectandra lanceolata.

In analyzing the values generated in the PCoA axis 1 (Table 1) in relation to resource allocation strategies (acquisitive and conservative), seven tree species showed conservative characteristics and 12 were considered acquisitive. The latter was the largest group, being represented by a predominance of species with faster strategies for investment in resources, i.e. water, light and nutrients, leaves with greater luminosity absorption per unit of biomass (specific leaf area), more membranous leaves, and most with greater growth in height and diameter.

The co-phenetic correlation coefficient for the cluster analysis (Figure 2) represented a satisfactory

Table 1 - Acquisitive and conservative tree species with their respective functional attributes, sampled in a secondary vegetation stretch of Seasonal Deciduous Forest, RS, Brazil.

Tabela 1 - Espécies arbóreas aquisitivas e conservativas, com seus respectivos atributos funcionais, amostradas em um trecho de vegetação secundária de Floresta Estacional Decidual, RS, Brasil.

\begin{tabular}{|c|c|c|c|c|c|c|c|c|}
\hline \multirow{2}{*}{$\begin{array}{l}\text { Group } \\
1-\text { Conservative species }\end{array}$} & \multicolumn{5}{|c|}{ Functional attributes } & \multicolumn{3}{|r|}{ PCoA } \\
\hline & $\begin{array}{c}\mathrm{LA} \\
\left(\mathrm{cm}^{2}\right)\end{array}$ & $\begin{array}{c}\text { SLA } \\
\left(\mathrm{cm}^{2} \mathrm{~g}\right)^{-1}\end{array}$ & $\begin{array}{l}\operatorname{Hmax}(\mathrm{m}) \\
(\mathrm{cm})\end{array}$ & Dmax & RG & DS & LR & $0.3781^{*}$ \\
\hline Apuleia leiocarpa (Vogel) J.F.Macbr. & 29.61 & 78.38 & 14.8 & 17.84 & $\mathrm{LDC}$ & An & $\overline{\mathrm{D}}$ & 0.2057 \\
\hline Cordia trichotoma (Vell.) Arráb. ex Steud. & 38.95 & 64.07 & 16.5 & 17.82 & LDC & An & $\mathrm{D}$ & 0.2132 \\
\hline Cedrela fissilis Vell. & 450.5 & 287.46 & 14.8 & 23.95 & LDC & An & $\mathrm{D}$ & 0.3046 \\
\hline Machaerium paraguariense & & & & & & & & \\
\hline Hassl. & 85.0 & 257.37 & 14.2 & 15.08 & LDC & An & $\mathrm{D}$ & 0.2414 \\
\hline Cabralea canjerana (Vell.) Mart. & 522.3 & 118.62 & 18 & 29.87 & LDC & Zo & $\mathrm{D}$ & 0.1243 \\
\hline Ficus luschnathiana (Miq.) Miq. & 36.75 & 104.02 & 14.45 & 33.07 & LDC & Zo & $\mathrm{D}$ & 0.0831 \\
\hline Casearia decandra Jacq. & 8.36 & 256.06 & 10.3 & 15.60 & STC & Zo & $\mathrm{D}$ & 0.0442 \\
\hline 2-Acquisitive species & $\begin{array}{l}\mathrm{LA} \\
\mathrm{cm}^{2}\end{array}$ & $\begin{array}{c}\text { SLA } \\
\mathrm{cm}^{2} \mathrm{~g}^{-1}\end{array}$ & $\begin{array}{c}\text { Hmaxm } \\
\mathrm{cm}\end{array}$ & Dmax & $\overline{\mathrm{RG}}$ & $\mathrm{DS}$ & LR & $0.3781^{*}$ \\
\hline Nectandra lanceolata Nees & 30.17 & 124.02 & 22.2 & 46.97 & LDC & Zo & $\mathrm{P}$ & -0.1186 \\
\hline Nectandra megapotamica (Spreng.) Mez & 18.83 & 142.87 & 18.75 & 40.30 & LDC & Zo & $\mathrm{P}$ & -0.1012 \\
\hline Ocotea puberula (Rich.) Nees & 39.14 & 245.59 & 18.3 & 39.54 & LDC & Zo & $\mathrm{P}$ & -0.0694 \\
\hline Cupania vernalis Cambess. & 294.6 & 105.96 & 14.3 & 20.02 & LDC & Zo & $\mathrm{P}$ & -0.0690 \\
\hline Matayba elaeagnoides Radlk. & 158.2 & 104.01 & 13.25 & 17.45 & LDC & Zo & $\mathrm{P}$ & -0.0788 \\
\hline $\begin{array}{l}\text { Allophylus edulis (A.St-Hil.et.al.) } \\
\text { Hieron. ex Niederl. }\end{array}$ & 26.21 & 163.56 & 11.5 & 15.19 & LDC & Zo & $\mathrm{P}$ & -0.0915 \\
\hline Annona neosalicifolia $\mathrm{H}$. Rainer & 35.62 & 228.81 & 8.2 & 12.29 & LDC & Zo & $\mathrm{P}$ & -0.0990 \\
\hline Cordia ecalyculata Vell. & 21.74 & 142.54 & 10.9 & 16.51 & LDC & Zo & $\mathrm{P}$ & -0.0983 \\
\hline Casearia sylvestris $\mathrm{Sw}$. & 18.84 & 165.26 & 13.95 & 16.85 & $\mathrm{LDC}$ & Zo & $\mathrm{P}$ & -0.0752 \\
\hline Inga marginata Willd. & 83.81 & 143.74 & 13.7 & 16.95 & LDC & Zo & $\mathrm{P}$ & -0.0743 \\
\hline Actinostemon concolor (Spreng.) Müll.Arg. & 15.94 & 92.99 & 4.75 & 6.47 & STC & $\mathrm{Au}$ & $\mathrm{P}$ & -0.1717 \\
\hline Guarea macrophylla Vahl & 334.1 & 114.3 & 9.9 & 21.53 & STC & Zo & $\mathrm{P}$ & -0.1690 \\
\hline
\end{tabular}

$\mathrm{LA}=$ leaf area; SLA = specific leaf area; Hmax = maximum height; Dmax = maximum diameter; RG = regeneration guilds $(\mathrm{STC}=$ shade-tolerant climax; LDC $=$ light-demanding climax $), \mathrm{DS}=$ dispersion syndrome $(\mathrm{Au}=$ autochorous; $\mathrm{An}=$ anemochoric; $\mathrm{Zo}=$ zoochoric $) ; \mathrm{LR}=$ leaf renewal regime $(\mathrm{P}=$ perennial evergreen; $\mathrm{D}=$ deciduous). * PCoA eigenvalue.

$A F=$ área foliar $; A F E=$ área foliar especifica $;$ Hmáx = altura máxima $;$ Dmáx = diâmetro máximo; GR $=$ guildas de regeneração $(C T S=$ clímax tolerante a sombra $;$ $C E L=$ clímax exigente de luz), $S D=$ síndrome de dispersão $(A u=$ autocórica; $A n=$ anemocórica; $Z$ Z = zoocórica $) ; R F=$ regime de renovação foliar $(P=$ perenifólia; $D=$ decídua). *autovalor da PCOA 
result regarding its interpretation, with a value of $91 \%$. The formation of two associated groups was verified by the functional dispersion syndrome attribute and regeneration guilds. The first group had two subdivisions, namely the zoochoric species subgroup and the other being anemochoric species, both being light-demanding and deciduous climax species. The second group was formed by the species divided between shade-tolerant climax and the largest subgroup formed by species belonging to the light-demanding climax with zoochoric dispersion syndrome and perennials.

Only Casearia decandra presented a different behavior when the ordering and dendrogram were analyzed together. The same species which belonged to the conservative group joined those of the group separated by the regeneration guild; in addition, the same division between species was observed in both identifying the functional groups and in separating the species into acquisitive and conservative.

A strong negative linear correlation was observed considering the correlation analysis between the continuous functional traits for the leaf area and specific leaf area, which indicates an inverse proportion. Moreover, they increase in the same proportion for maximum height and maximum diameter (H/D ratio). No linear relationship was found for the other correlations which shows dependence between them (Figure 3).
Three environmental variables related to the soil properties and relief were significant, explaining $46 \%$ of the functional attributes in the RDA analysis (Figure 4), with the first axis explaining $46.07 \%$ and the second with $32.24 \%$.

Mean height was related to species with larger leaves, indicating that they were preferential for those which invest more in leaf construction in the higher parts of the forest stretch, presenting a higher dry matter content and are generally more coriaceous. Opposite to the leaf area vector (LA), the species with the largest specific leaf areas were preferred in soils with the highest potassium concentration and in the places with the lowest variations in altitude. The attributes related to height and DBH were closely related to soil $\mathrm{pH}$.

\section{DISCUSSION}

The most representative species sampled together with their functional attributes demonstrated how the composition of an arboreal community is formed over time. In view of their ecological strategies and interactions with local conditions, species have mechanisms to establish, develop and maintain their population in different environmental conditions (Soboleski et al., 2017; Missio et al., 2017; Mason et al., 2005). This is due to the variation in the functional attributes of each plant, as well as the phenotypic plasticity between

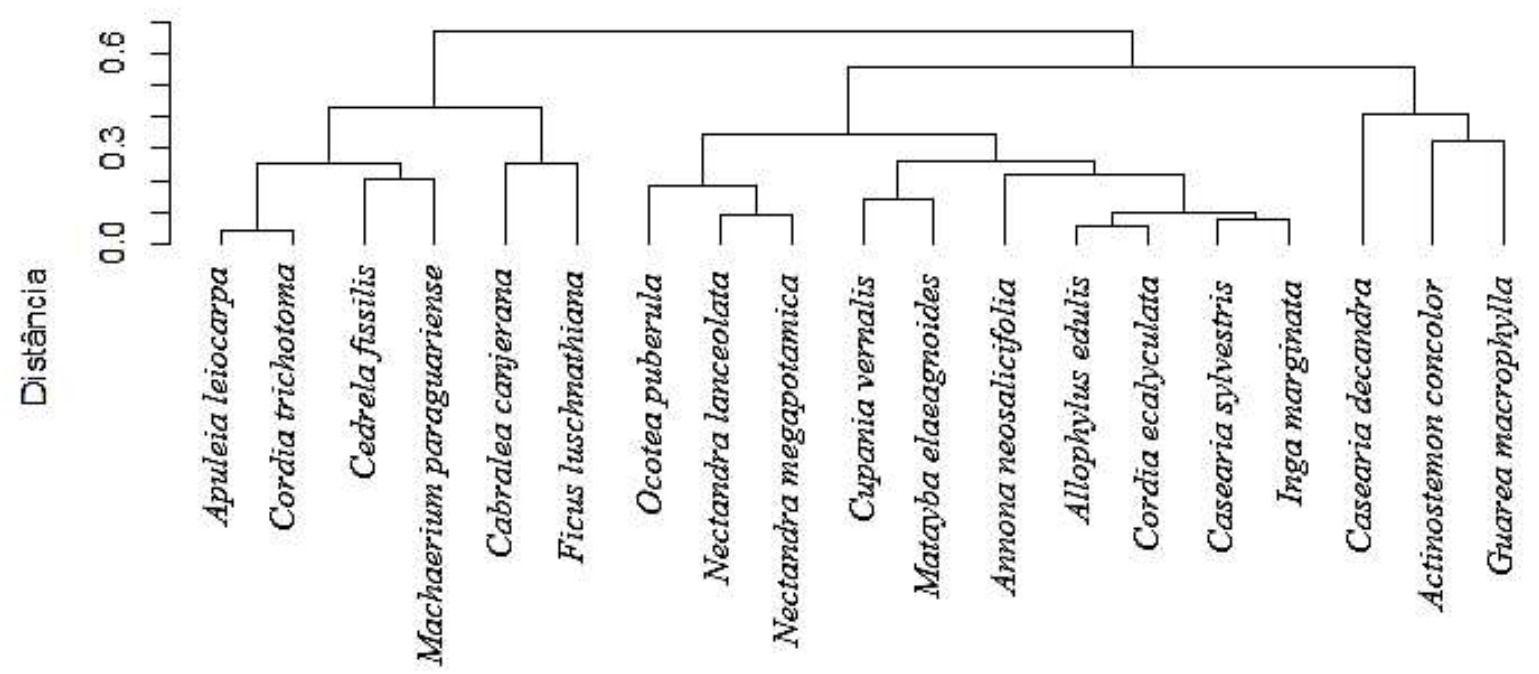

Figure 2 - Dendrogram used to check species organization according to their ecological strategies.

Figura 2 - Dendrograma utilizado para verificar a organização das espécies de acordo com suas estratégias ecológicas.

Revista Árvore 2020;44:e4423 


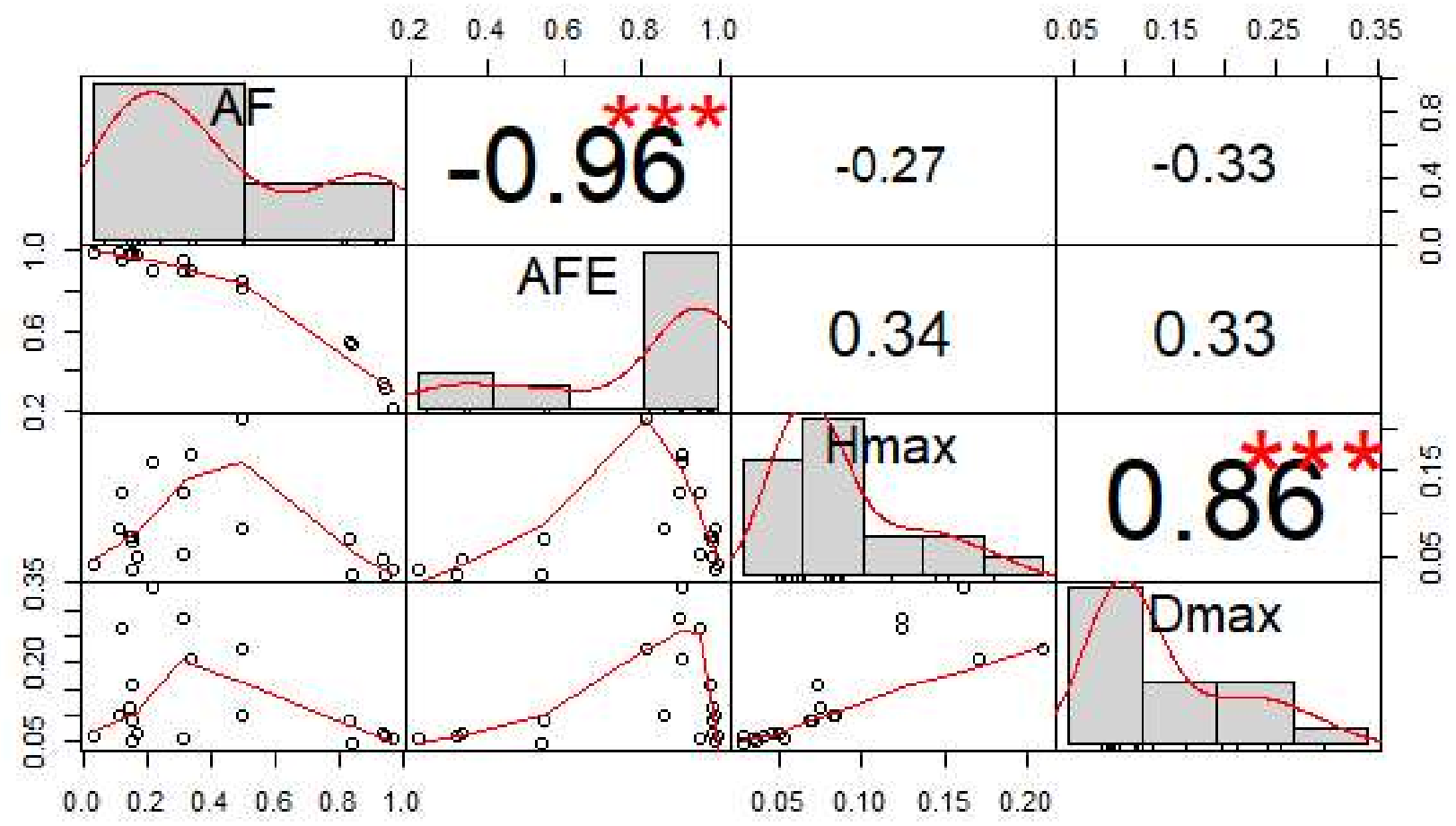

Figure 3 - Pearson's correlation between the continuous functional traits related to the 19 most abundant species in Seasonal Deciduous Forest, RS, Brazil, 2019. Where: LA = leaf area; SLA = specific leaf area; Hmax = maximum height; Dmax = maximum diameter. Numerical values $=$ positive or negative eigenvalues presented according to the degree of association (the closer to the extremes the greater the positive or negative linear relationship).

Figura 3 - Correlação de Pearson entre os a traços funcionais contínuos relacionados as 19 espécies mais abundantes em Floresta Estacional Decidual, $R S$, Brasil, 2019. Em que: $A F=$ área foliar; $A F E=$ área foliar especifica; Hmax = altura máxima; Dmax = diâmetro máximo. Valores numéricos = autovalores positivos ou negativos apresentados de acordo com o grau de associação (quanto mais próximo aos extremos maiores é a relação de linear positiva ou negativa).

them (Scheiner et al., 2016) which present a trade-off relationship between theirstrategies given the conditions imposed by the environment (Baraloto et al., 2005) such as variations in leaf size or photosynthetic capacity due to investment in biomass, both inversely proportional, in relation to light capture (Reich et al., 2003). Still, the positive relationship between height and diameter is due to the proportion of vertical investment by the plant and mechanical support of the stem/trunk, which is an important association for the plant's strategy in terms of competitive vigor, growth form and resilience to environmental disturbances (Pérez-Harguindeguy et al., 2013).

For Chazdon (2016), the composition of an arboreal community depends on the functional characteristics of the species associated with the set of environmental variations, in which the populations pass through ecological filters when seedlings are in the recruitment phase and so forth successively until the adult phase, with dispersion being the first filter for this author. As a rule of thumb, seed dispersal assists in conditioning forest regeneration and propagating propagules, as demonstrated by Chen et al. (2018). This functional attribute influenced the floristic diversity, and the greater representativeness of zoochoric species represented the interaction between flora and fauna as mechanisms of coexistence, and which has already been very well reported in the other secondary forests of the southern region (Scipioni et al., 2013; Negrini et al., 2012; Budke et al., 2005).

Nevertheless, to germinate and remain in the different strata of the forest, the division of species according to the need for light is the transformation sequence and structure of the tree component, meaning that it corroborates with what was observed for most species belonging to the light-demanding 


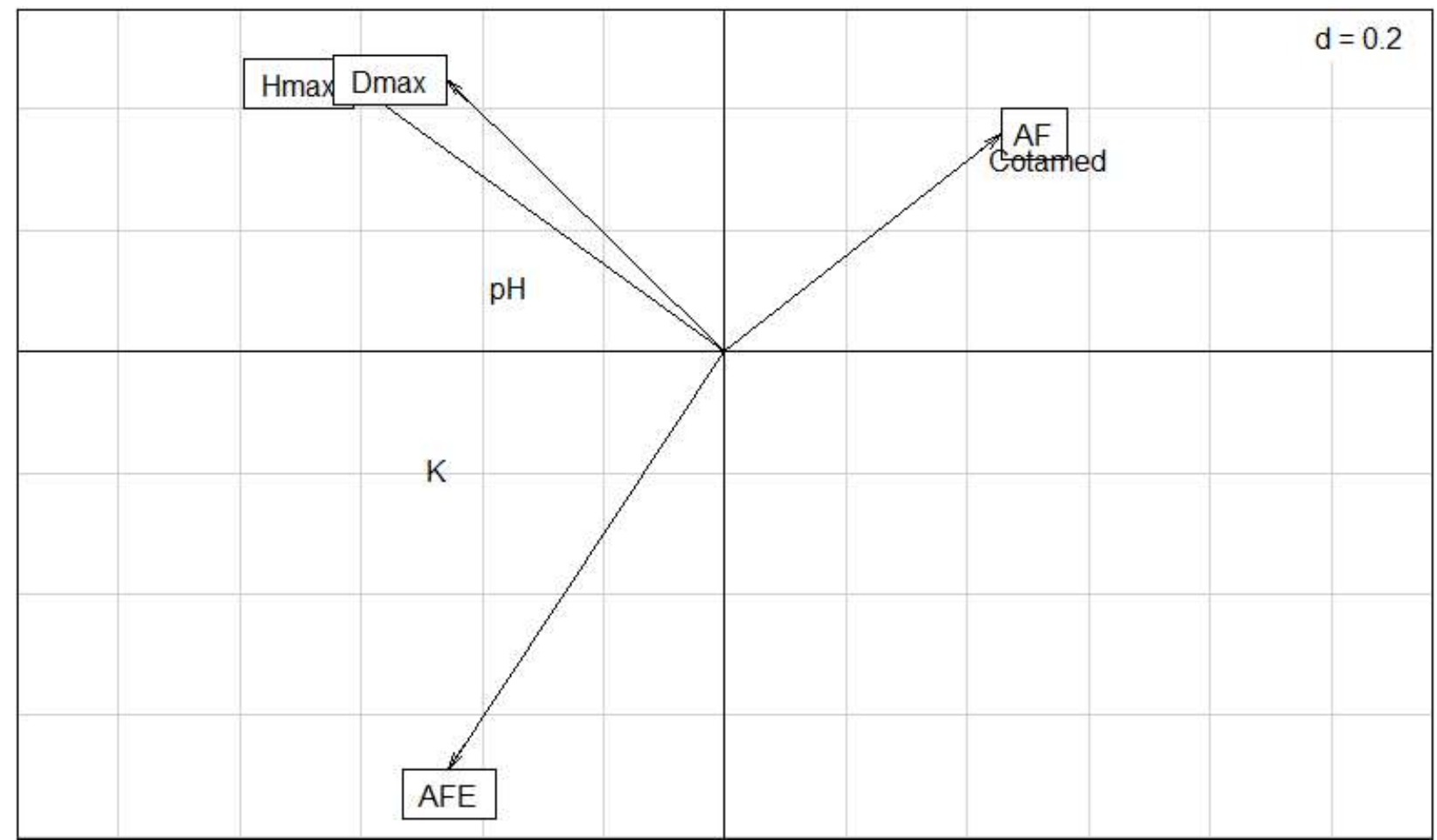

Figure 4 - CWM-RDA analysis in relation to the five continuous functional traits and significant environmental variables (p $<0.1$ ). Where: LA = leaf area; SLA = specific leaf area; $\mathrm{Hmax}=\operatorname{maximum}$ height; Dmax = maximum diameter; $\mathrm{pH}=\mathrm{pH}$ in $\mathrm{H}_{2} \mathrm{O} ; \mathrm{K}=$ potassium; average elevation (Cotamed).

Figura 4 - Análise CWM-RDA em relação aos cinco traços funcionais contínuos e variáveis ambientais significativas (p < 0,1). Em que: $A F=$ área foliar; $\mathrm{AFE}=$ área foliar especifica; Hmax = altura máxima; Dmax $=$ diâmetro máximo; $\mathrm{pH}=\mathrm{pH}$ em $\mathrm{H}_{2} \mathrm{O} ; \mathrm{K}=$ potássio; cota média (Cotamed).

climax species. This functional attribute represented the species' similarity in the process of covering the tree layer and consequently continuity in the forest succession. In a condition of high light availability after disturbances, pioneer species become specialists in colonizing and establishing these areas. However, they show a reduction in relation to survival and growth under conditions of canopy closure and greater shading along the secondary succession, thus opening conditions for species replacement which occur in "vertical waves" after canopy coverage from the understory towards the canopy (Chazdon, 2016).

While the coexistence of species in functional groups was observed in the assembly of the tree community, it is then stated (in this case) that in an area which has undergone anthropic intervention with a change in the floristic composition and subsequently its restoration, the dispersion syndrome and regeneration guilds were the two most important ecological attributes for secondary succession in the forest stretch.
Furthermore, the environment itself was favorable for the rapid return on investment of available resources for organizing these species when verifying that acquisitive species form the largest number of conservative species, meaning they are related to growth, reproduction and development. In this regard, the Casearia silvestris species stands out, which had greater abundance and representativeness in the tree community, with the same being found by Silva et al. (2015) in an area of secondary vegetation as an acquisitive species.

Acquisitive species generally perform rapid optimization of resources such as water, light, and nutrients, and therefore show rapid growth in height and leaf investment in relation to the availability of light (Donovan et al., 2011). On the other hand, conservative species are generally slower in their allocation with a low specific leaf area, low photosynthetic rate, less longlived leaves and larger sizes; however, they invest more in defense mechanisms (herbivory) than acquisitive mechanisms (Poorter et al., 2009).

Revista Árvore 2020;44:e4423 
According to Silva et al. (2015), acquisitive species in forest areas in the initial and intermediate stages of succession are easily established by training and optimizing the resources available in the environment. This fact was also observed by Pyles et al. (2018), where they found that secondary tropical forests in recent succession stages presented species with ecological strategies showing values characteristic of those belonging to the acquisitive group. According to Lohbecki et al. (2014), this is because environmental filtration selects these functionally similar species. However, species considered conservative tend to establish themselves throughout the succession process and are preferred in more advanced stages in which the dominant ecological process is competition and environmental resources are scarcer (Wright, 2004; Lohbeck et al., 2014).

The indicator for acquisitive and conservative species in the area demonstrated great potential for resilience in the forest in which the species are functionally redundant in their respective groups. Moreover, the presence of two ecological interactions (competitive interaction and environmental filtering) guide ecosystem processes and support the forest structure. Still, according to Chazdon (2016) and Pillar et al. (2013), recent forests in successional stages have equivalent species which perform redundant activities in order to compose the ecological structure of the tree community, being resilient to disturbances and the respective environmental filters.

When analyzing the functional attributes with the environmental variables, there was a close relationship with the local conditions of the relief and soil variables. Studies such as those by Missio et al. (2016), Sousa et al. (2017) and Soboleski et al. (2017) have already portrayed the influence of environmental conditions on the coexistence of species and their functional attributes in forests in the southern region. The occurrence of more conservative species with larger leaves in higher places of the forest stretch directly reflects the relationship of this functional attribute as an advantage in absorbing light, in contrast to species which have leaves with a smaller specific leaf area that invest in fast growth to capture light and less in leaf construction (Cornelissen et al., 2003).

Furthermore, growth in height and diameter related to the $\mathrm{pH}$ in the soil reflects the species' ability to develop according to the partition of their ecological niches, reflecting on the species selection mechanisms in the organization of an arboreal community (Diaz et al., 2004). In turn, Missio et al. (2016) also verified the relationship of $\mathrm{pH}$ in the soil with characteristics related to the growth of tree species.

\section{CONCLUSION}

It was found that the functional attributes analyzed in the composition of the main tree species were important for the successional processes in response to the disturbances, and that they guided forming groups of functionally similar species. In turn, these are characteristic of forests in regeneration stages, with the most abundant being acquisitive species. It was also observed that the two attributes which best represent the forest in a secondary forest stage were the dispersion syndrome and regeneration guilds. Lastly, functional attributes represented the different strategies of the species in response to environmental variables in allocating the available resources in the respective study area and thus establish growth-survival in view of the partition of niches in local conditions.

\section{REFERENCES}

Alvares CA, Stape JL, Sentelhas PC, Gonçalves JLM, Sparovek G. Köppen's climate classification map for Brazil. Meteorologische Zeitschrift. 2013;22(6):711-28. doi:10.1127/09412948/2013/0507

Baraloto C, Goldberg DE, Bonal D. Performance trade-offs among tropical tree seedlings in contrasting microhabitats. Ecology. 2005:86(9):2461-72.

Borcard D, Gillet F, Legendre P. Numerical Ecology with R. New York: Springer; 2011. 306 p.

Budke JC, Athayde EA, Giehl ELH, Záchia RA, Eisinger SM. Composição florística e estratégias de dispersão de espécies lenhosas em uma floresta ribeirinha, arroio Passo das Tropas, Santa Maria, RS, Brasil. Iheringia. 2005;60(1):17-24.

Carvalho PER. Espécies arbóreas brasileiras. Brasília, DF: Embrapa Informação Tecnológica; Colombo, PR: Embrapa Florestas; 2003. 1039 p. v.1.

Cornelissen JHC, Lavorel S, Garnier E, Díaz S, Buchmann N, Gurvich DE, et al. Handbook of

Revista Árvore 2020;44:e4423 
protocols for standardised and easy measurement of plant functional traits worldwide. Australian Journal of Botany. 2003:51(4):335-80.

Chazdon RL. Renascimento de Florestas: regeneração na era do desmatamento. São Paulo: Oficina de textos; 2016. 431 p.

Chen K, Burgess KS, Yang XY, Luo YH, Gao LM, Li DZ. Functional trade-offs and the phylogenetic dispersion of seed traits in a biodiversity hotspot of the Mountains of Southwest China. Ecology and Evolution. 2018;8(4):2218-30.

Diaz S, Hodgson JG, Thompson K, Cabido M, Cornelissen JHC, Jalili A, et al. The plant traits that drive ecosystems: evidence from three continents. Journal of Vegetation Science. 2004;15(3):295-04.

Donovan LA, Maherali H, Caruso CM, Huber H, Kroon H, et al. The evolution of the worldwide leaf economics spectrum. Trends in Ecology and Evolution. 2011;26(2):88-95.

Empresa Brasileira de Pesquisa Agropecuária EMBRAPA. CNPS- Centro Nacional de Pesquisa de Solos. Manual de métodos de análise de solos. 2. ed. Rio de Janeiro; 2011.

Freitas JR, Mantovani W. An overview of the applicability of functional diversity in Biological Conservation. Brazilian Journal of Biology. 2017;78(3):517-24.

Garnier E, Cortez J, Billés G, Navas ML, Roumet C, Debussche M, et al. Plant functional markers capture ecosystem properties during secondary succession. Ecology. 2004;85(9):2630-37.

Gower JC. A general coefficient of similarity and some of its properties. Biometrics. 1971;27(4):857-74.

Fundação Instituto Brasileiro de Geografia e Estatística - IBGE. Manual técnico da vegetação brasileira. 2. ed. Rio de Janeiro: IBGE; 2012. 275 p.

Laurance WF, Nascimento HEM, Laurance SG, Andrade A, Ribeiro JELS, Giraldo JP, et al. Rapid decay of tree-community composition in Amazonian forest fragments. Proceedings of the National Academy of Sciences. 2006;103(50):19010-014.

Laureto LMO, Cianciaruso MV, Samia DSM.
Functional diversity: an overview of its history and applicability. Brazilian Journal of Nature Conservation. 2015;13(2):112-16.

Legendre P, Legendre L. Numerical ecology. 2ed. Amsterdam: Elsevier; 1998. 852 p.

Lemmon PE. A new instrument for measuring fores tover story density. Journal of Forestry. 1957;55(9):667-68.

Lohbeck M, Poorter L, Martínez-Ramos M, Rodriguez-Velázquez J, van Breugel $\mathrm{M}$, Bongers F. Changing drivers of species dominance during tropical forest succession. Functional Ecology. 2014;28(4):1052-58.

Lorenzi H. Árvores Brasileiras: manual de identificação e cultivo de plantas arbóreas nativas do Brasil. 2. ed. Nova Odessa: Instituto Plantarum; 1998.

Lorenzi H. Árvores Brasileiras: manual de identificação e cultivo de plantas arbóreas nativas do Brasil. 3. ed. Nova Odessa: Instituto Plantarum; 2000.

Mason NWH, Mouillot D, Lee WG, Wilson JB. Functional rich-ness, functional evenness and functional divergence: the primary components of functional diversity. Oikos. 2005;111(1):112-18.

Mayfield MM, Ackerly D, Daily GC. The diversity and conservation of plant reproductive and dispersal functional traits in human-dominated tropical landscapes. Journal of Ecology. 2006;94(3):522-36.

Missio FF, Higuchi P, Silva AC, Longhi SJ, Salami B, Rosa AD, et al. Trade-offs and spatial variation of functional traits of tree species in a subtropical forest in southern Brazil. IFOREST. 2016;9:855-59.

Missio FF, Silva AC, Higuchi P, Longhi SJ, Brand MA, Rios PDA, et al. Atributos funcionais de espécies arbóreas em um fragmento de Floresta Ombrófila Mista em Lages - SC. Ciência Florestal. 2017;27(1):215-24.

Missio FF, Resiliência e Estrutura de uma comunidade arbórea em Floresta Estacional Decidual no sul do Brasil. 2019. 158 p. Tese. (Doutorado em Engenharia Florestal) - Universidade Federal de Santa Maria, Santa Maria, RS, 2019. 
Negrini M, Aguiar MD, Vieira CT, Silva AC, Higuchi P. Dispersão, distribuição espacial e estratificação vertical da comunidade arbórea em um fragmento florestal no planalto catarinense. Revista Árvore. 2012;36(5):919-30.

Oliveira- Filho AT, Vilela EA, Carvalho DA, Gavilanes ML. Differenciation of streamside and upland vegetation in na área of montane semideciduous Forest in southeastern Brasil. Flora. 1994; 189(4):287-05.

Pedron FA, Dalmolin RS. Solos da região do Rebordo do Planalto Meridional no Rio Grande do Sul. In: Schumacher MV, Longui SJ, Brun EJ, Kilka RV (eds.). A Floresta Estacional Subtropical: caracterização e ecologia no Rebordo do Planalto Meridional. Santa Maria: Editora Pallotti; 2011. p. 33-51.

Pérez-Harguindeguy N, Díaz S, Garnier E, Lavorel S, Poorter H, Jaureguiberry P, et al. New handbook for standardised measurement of plant functional traits wordwide. Australian Jounal of botany. 2013;61(3):167-234

Pillar VD, Blanco CC, Müller SC, Sosinski EE, Joner F, Duarte LDS. Functional redundancy and stability in plant communities. Journal of Vegetation Science. 2013;24:963-74.

Poorter H, Niinemets Ü, Poorter L, Wright IJ, Villar R . Causes and consequences of variation in leaf mass por area (LMA): a meta-analysis. New Phytologist. 2009;182(3):565-88.

Pyles MV, Prado-Junior JA, Magnago Luiz FS, Paula A, Meira-Neto JAA. Loss of biodiversity and shifts in aboveground biomass drivers in tropical rainforests with diferent disturbance histories. Biodiversity and Conservation. 2018;27:3215-31.

R Development Core Team. R: A language and environment for statistical computing. Vienna, Austria: R Foundation for Statistical Computing; 2018.

Available at: <URL https://www.R-project.org/>.

Rasband WS. ImajeJ, version 1.42q. USA: National Institute of Health; 2007.

Reich PB, Wright IJ, Cavender-Bares J, Craine JM, Oleksyn J, Westoby M, et al. The evolution of plant functional variation: traits, spectra, and strategies. International Journal of Plant Sciences. 2003;164(3
Suppl.):S143-S164.

Reich PB. The world-wide 'fast-slow' plant economics spectrum: a traits manifesto. Journal of Ecology. 2014;102(2):275-301.

Santos RD, Lemos RC, Santos HG, Ker JC, Anjos LHC, Shimizu SH. Manual de descrição e coleta de solo no campo. 6. ed. Viçosa: Sociedade Brasileira de Ciência do Solo; 2013.

Scipioni MC, Galvão F, Longhi SJ. Composição florística e estratégias de dispersão e regeneração de grupos florísticos em Florestas Estacionais Deciduais no Rio Grande do Sul. Floresta. 2013;43(2):241-54.

Scheiner SM, Kosman E, Presley SJ, Willig MR. Decomposing functional diversity. Methods in Ecology and Evolution. 2016;8(7):809-20. doi: 10.1111/2041-210X.12696

Silva MAM, Pinto AVF, Nascimento LM, Linse-Silva ACB, Lima ALA, Rodal MJN. Does the plant economics spectrum change with secondary succession in the forest?. Trees. 2015;29(5):1521-31.

Soboleski VF, Silva AC, Loebens R, Souza K, Buzzi Junior F, Lima CL. Variação de atributos funcionais do componente arbóreo em função de gradientes edáficos em uma floresta nebular no sul do Brasil. Rodriguésia. 2017;68(2):291-300.

Sosinski-Júnior EE, Pillar VDP. Respostas de tipos funcionais de plantas á intensidade de pastejo em vegetação campestre. Pesquisa agropecuária brasileira. 2004;39(1):1-9.

Sousa K, Higuchi P, Silva AC, Schimalski MB, Loebens R, Buzzi Júnior F, et al. Partição de nicho por grupos funcionais de espécies arbóreas em uma Floresta Subtropical. Rodriguésia. 2017;68(4):1165-75.

Van der Pijl L. Principles of dispersal in higher plants. Berlin: Springer-Verlag; 1982. 162 p.

Violle C, Navas ML, Vile D, Kazakou E, Fortunel C, Hummel I, Garnier E. Let the concept of trait be functional! Oikos. 2007;116(5):882-92.

Wright IJ, Reich PB, Westoby M, Ackerly DD, Baruch Z, Bongers F, et al. The worldwide leaf economics spectrum. Nature. 2004;428(6985):821-27. 